\title{
Articles
}

\section{The New ASERVIC Competencies for Addressing Spiritual and Religious Issues in Counseling}

\author{
Craig S. Cashwell and Richard E. Watts
}

In 2009, leaders in the Associotion for Spiritual, Ethical and Religious Values in Counseling (ASERVIC) developed new competencies for addressing spiritual and religious issues in counseling. This article briefly addresses the need for new ASERVIC competencles, provides an overvlew of the process whereby the new competencles emerged, and concludes with a listing of the new ASERVIC-endorsed competencies.

n May 2009, the Board of Directors of the Association for Spiritual, Ethical and Religious Values in Counseling (ASERVIC) voted unanimously to approve the newly revised competencies for addressing spiritual and religious issues in counseling. The new ASERVIC competencies may be found in the Appendix as well as on the ASERVIC website (http://www.aservic.org/).

The purpose of this article is to address why the ASERVIC leadership deemed new competencies necessary, as well as provide a brief overview of the process whereby the new ASERVIC competencies emerged. In addition, this article serves to archive the competencies in the journal sponsored by the organization that developed them.

\section{Why New Competencies?}

In 1995, a group of counselors and counselor educators gathered for the first Summit on Spirituality. Challenged even to define spirituality given its numinous qualities, the Summit working group ultimately developed a description of spirituality and a set of competencies that would support counselors in serving clients from various religious and spiritual traditions. After a series of town hall meetings at professional conferences over several years, at which the competencies were discussed and refined by the Summit working group, a final draft was submitted for acceptance by ASERVIC. These competencies were endorsed by ASERVIC and have since been en-

Craig S. Cashatell, Department of Counseling and Educational Development, University of North Carolina at Greensboro, Richard E. Watts, Department of Edtcational Leadership and Counseling, Sam Houston State University. Correspondence concening this article should be addressed to Richard E. Watts, Departnent of Educational Leadership and Connseling, Sam Houston State University, PO Box 2119 , Huntsville, $T X 77341+2119$ ( matl rewoo3@shsuedu).

02010 by the American Counseling Association. All rights reserved. 
dorsed by the American Counseling Association Governing Council. The competencies were first archived in the Journal of Counseling $\&$ Development (Miller, 1999) and provided the impetus for a textbook for counselors and counselor educators (Cashwell \& Young, 2005).

The establishment of these competencies was groundbreaking and supported the burgeoning groundswell of interest in spiritually sensitive counseling. The competencies were not, however, without some problems. Cashwell and Young (2005) chose to combine Competency 8 ("The professional counselor is sensitive to and receptive of religious and/or spiritual themes in the counseling process as befits the expressed preference of each client") and Competency 9 "'The professional counselor uses a client's religious and/or spiritual beliefs in the pursuit of the client's therapeutic goals as befits the client's expressed preference"), arguing that the two were inseparable at a practical level. There were also issues of clarity of language. What had been abundantly clear to the Summit working group when they developed the competencies was, at times, less clear to others. Furthermore, the original competencies emerged at a time in the counseling profession when leaders were still arguing for the legitimacy of including spirituality and religion within the counseling process. In time, however, the argument has changed from whether to include spirituality and religion into counseling to how best to do this, that is, from "if" to "how" (Briggs \& Rayle, 2005). Finally, although the original competencies emerged through a diligent process from a working group, there is limited empirical validation (Young, Cashwell, Wiggins-Frame, \& Belaire, 2002). Because of this, ASERVIC leaders opted to convene another Summit, called Summit II, beginning in the summer of 2008. One of the primary tasks of Summit II was to revise the competencies.

\section{Summit 11}

In the fall of 2007, Lisa Jackson-Cherry, ASERVIC president, asked Craig Cashwell to serve as coordinator of Summit II. Working with ASERVIC leaders, Cashwell convened meetings in the summer of 2008 and spring of 2009. Participants included various leaders and scholars in spirituality and counseling, including Michele Kielty Briggs, Sharon Cheston, Chris Faiver, Bryce Hagedorn, Grant Hayes, Lisa Jackson-Cherry, Geri Miller, Judy Miranti, Linda Robertson, Mike Robinson, Cheri Smith, Richard Watts, Marsha Wiggins, Mark Young, and Scott Young.

In the summer of 2008 , the Summit II group brainstormed and discussed what was needed to further promote spirituality and religion within the counseling process. One of the key priorities that emerged from this discussion was the need for revised competencies, and this quickly became a primary focus for the Summit II group. In wondrous synchronicity, Linda Robertson, then a doctoral candidate at the University of Central Florida, was conducting a large-scale factor analysis $(N=662)$ of the original nine competencies for her doctoral dissertation. Using acceptable criteria for item retention in a factorial procedure, Robertson's research found a six-factor 
solution with acceptable temporal stability and internal consistency. In fact, the internal consistency of all items was quite strong $(\alpha=88)$. (Note. The article titled "The Spiritual Competency Scale" in this issue of Counseling and Values describes Robertson's research) Robertson's six-factor solution provided a solid empirical foundation for the revised competencies for addressing spiritual and religious issues in counseling that were drafted in April 2009. These revised competencies were reviewed by all members of the Summit II group after the meeting, and minor modifications were made. This document was presented to the ASERVIC Board of Directors, who approved, endorsed, and copyrighted the revised competencies in May 2009.

\section{References}

Association for Spiritual, Ethical and Religious Values in Counseling. (2009). Spiritual competencies: Competenties for addressing spiritual and religious issues in counseling. Retrieved from http:// www.aservic.org/

Briggs, M. K., \& Rayle, A. D. (2005). Incorporating spirituality into core counseling courses: Ideas for classroom application. Counseling and Values, 50, 63-75.

Cashwell, C. S., \& Young, J. S. (Eds.). (2005). Integrating spirituality and religion into counseling: A guide to competent practice. Alexandria, VA: American Counseling Association.

Miller, G. [1999]. The development of the spiritual focus in counseling and counselor education. Joumal of Counseling \& Development, 77, 498-501.

Young, J. S., Cashwell, C., Wiggins-Frame, M., \& Belaire, C. [2002). Spiritual and religious competencies: A national survey of CACREP-accredited programs. Counseling and Values, 47, 22-33. 


\section{APPENDIX}

\section{Association for Spiritual, Ethical and Religious Values in Counseling (ASERVIC) Competencies for Addressing Spiritual and Religious Issues in Counseling}

\section{Culture and Worldview}

1. The professional counselor can describe the similarities and differences between spirituality and religion, including the basic beliefs of various spiritual systems, major world religions, agnosticism, and atheism.

2. The professional counselor recognizes that the client's beliefs (or absence of beliefs) about spirituality and/or religion are central to his or her worldview and can influence psychosocial functioning.

\section{Counselor Self-Awareness}

3. The professional counselor actively explores his or her own attitudes, beliefs, and values about spirituality and/or religion.

4. The protessional counselor continuously evaluates the influence of his or her own spiritual and/or religious beliets and values on the client and the counseling process.

5. The professional counselor can identily the limits of his or her understanding of the client's spiritual and/or religious perspective and is acquainted with religious and spiritual resources, including leaders, who can be avenues for consultation and to whom the counselor can reler.

\section{Human and Spiritual Development}

6. The professional counselor can describe and apply various models of spiritual and/or religious development and their relationship to human development.

\section{Communication}

7. The professional counselor responds to client communications about spirituality and/or religion with acceptance and sensitivity.

8. The professional counselor uses spiritual and/or religious concepts that are consistent with the client's spiritual and/or religious perspectives and that are acceptable to the client.

9. The professional counselor can recognize spiritual and/or religious themes in client communication and is able to address these with the client when they are therapeutically relevant.

\section{Assessment}

10. During the intake and assessment processes, the professional counselor strives to understand a client's spiritual and/or religious perspective by gathering information from the client and/ or other sources.

\section{Diagnosis and Treatment}

11. When making a diagnosis, the professional counselor recognizes that the client's spiritual and/or religious perspectives can a) enhance well-being; b) contribute to client problems; and/or c) exacerbate symptoms.

12. The professional counselor sets goals with the client that are consistent with the client's spiritual and/or religious perspectives.

13. The professional counselor is able to a) modify therapeutic techniques to include a client's spiritual and/or religious perspectives, and b) utilize spiritual and/or religious practices as techniques when appropriate and acceptable to a client's viewpoint.

14. The professional counselor can therapeutically apply theory and current research supporting the inclusion of a client's spiritual and/or religious perspectives and practices.

Note. Revised and approved May 5, 2009, by ASERVIC Board of Directors. Copyright 2009 by ASERVIC. Reprinted with permission. 